Digital Press Social Sciences and Humanities

The Effect of Photo Level Quality on Instagram to Millennial Tourism Visit at Tourism Attractions in West Bandung District

Kusherdyana R, Haifa Dwi Fardiana Muharani, Muhammad Arifian Pratama and Wirya Muhammad Syakur Suwandi

Proceeding of Indonesia Heritage Tourism Forum 2019 (IHTF 2019)

Dewi Pratika Ayu Dhira Pradati (eds) 


\title{
The Effect of Photo Level Quality on Instagram to Millennial Tourism Visit at Tourism Attractions in West Bandung District
}

\author{
Kusherdyana R*, Haifa Dwi Fardiana Muharani, Muhammad Arifian Pratama, Wirya Muhammad \\ Syakur Suwandi
}

NHI Bandung Institute of Tourism, Bandung, Indonesia

*e-mail: herrykusherdyana@yahoo.com

\begin{abstract}
This study aims to reveal how much influence the quality of photo uploads by the user-generated content on Instagram has on the decisions of millennial tourists visiting tourist attractions in West Bandung Regency. The research method used is descriptive verification. The sample members were tourists who visited tourist attraction in West Bandung Regency, amounting to 100 people, who were selected by convenience sampling technique. The results of the study showed that there was an influence on the quality of photo uploads by the user-generated content on Instagram on the decisions of millennial tourists visiting tourist attractions in West Bandung Regency.
\end{abstract}

\section{Keywords}

decisions of visiting, millenial tourist, the quality of photo

\section{Introduction}

The rapid technological change towards the digital era is shaping a new lifestyle in society. Society is becoming increasingly global, easily accessible, and more mobile. Technology users in the digital age are increasing rapidly, especially among millennials. The millennial generation is the generation born between the 1980s and 2000s (Kaifi, Nafei, Khanfar, \& Kaifi, 2012) This millennial generation or Generation Y is the people aged 16 to 30 years (Pemerintah Indonesia, 2009). Considered the first generation born in the information age, and for this reason, they are considered as digital natives (Prensky, 2010). Millennials use this technology to share information and socialize. This information sharing and socializing activity then gave birth to a media called social media, an internet-based application that builds on the ideology and Web 2.0 technology foundation, thus enabling one to create and exchange content (Carr \& Hayes, 2015; Kaplan \& Haenlein, 2010).

Social media has an impact on tourism, especially on how tourists access and use tourism information (Xiang, Magnini, \& Fesenmaier, 2015). Most of all the tourists in the world use social media to get ideas or inspiration about destinations, hotels, vacation activities, attractions, and restaurants. This social media influences the tourism environment by changing the behavior of tourists and the business sector (Munar \& Jacobsen, 2014). With the growing use of mobile phones and other small devices in everyday life and the availability of various social media platforms, online photo sharing has become a social activity that is usually done by anyone at this time. Especially in tourism and hospitality, photography is an integral part of the traveling experience, and sharing photos is an important activity in documenting, animating, and sharing these experiences (Garrod, 2008; MacKay \& Fesenmaier, 1997; Markwell, 1997). Nowadays, more and more tourists are sharing their tourist experiences by posting photos online. Photos provide abundant information about travel and tourism (Deng, Liu, Dai, \& Li, 2019). The cognitive aspects of potential tourists become aroused when they see photos uploaded on social networks and their emotions are influenced by these photos (Kim \& Stepchenkova, 2015). Of course, the photos shared must be attractive and of good quality. Quality photos must pay attention to exposure (Burhanuddin, 2014). Exposure is a combination of three important factors, namely the aperture (diaphragm), shutter speed (shutter speed), and ISO (storage media sensitivity). A diaphragm or aperture is a measure of the size of the lens opening. The point is to regulate the level of light entering the film. Shutter speed is the speed of the shutter curtain to open and 
close again. The speed of the shutter curtain passes light from the lens determines the quantity of light that passes to light up the image. ISO is a number that indicates the film's sensitivity to light. The smaller the ISO number, the lower the sensitivity to light and vice versa (Peterson, 2010).

Several types of social media include YouTube, Pinterest, Snapchat, and Instagram. Instagram is a social networking application that allows its users to share photos and videos from smartphones. Instagram is the first social media site specifically designed to work on mobile devices. The specialty of Instagram is that the choices are simple and the navigation is clear and easy to understand. According to the WeAreSocial.net and Hootsuite survey results, Instagram is the seventh-largest number of social media platforms in the world. Total Instagram users in the world in January 2018 reached 800 million people. The most active Instagram users are in the United States, with 110 million people, followed by Brazil with 57 million people, and Indonesia in third place with 55 million people. In Indonesia, Instagram is the fourth most used social media after Youtube, Facebook, and Whatsapp. Instagram users on average share 95 million photos and videos every day (Parker, 2016). Most (90\%) Instagram users are younger than 35 years (Bagadiya, 2017; Smith, 2016).

Although there are many studies relating to various aspects of photography in tourism, for example, research on sharing tourist photos (Lo, McKercher, Lo, Cheung, \& Law, 2011), the correlation between photo content and tourist motivation (Pan, Lee, \& Tsai, 2014), the effect of photos on the desire to visit (Kim \& Stepchenkova, 2015), the effect of photo uploads on Instagram on visiting behavior (Windani, 2016), the effect of electronic word of mouth on visiting decisions (Hasan \& Setiyaningtiyas, 2015), the effect of social media variables on tourist visit decisions (Debby, 2016), E-WOM's influence on the decision to visit tourist attractions (Mustikasari \& Widaningsih, 2017), but there are no studies that reveal the effect of photos uploaded by tourists (User Generated Content) on Instagram on tourist visiting decisions. This research is important to do because one of the things that attracts tourists to visit a destination is physical evidence that can be seen visually, namely photos or photography. As expressed by Woodside \& Lysonski (1989), that the description of destinations obtained through photographs can influence the decision to visit a destination. Furthermore, photographs or photography created by tourists will provide extraordinary support for the number of tourist visits to a destination.

Basically, the decision to travel is adapted from the theory of visiting decisions, that is, someone spends money to get satisfaction and experience. This decision-making process includes several phases and aspects. Most studies of consumer behavior refer to five stages in the decision making process, namely: introduction of problems or identifying needs, gathering information, evaluating alternatives, choosing and decision processes, and post-purchase behavior (Kotler \& Keller, 2016). Some factors that influence purchasing decisions are cultural, social, personal, and psychological factors (Kotler \& Armstrong, 2017). Cultural factors are the most fundamental causes of one's desires and behavior. Human behavior is largely studied (Kotler \& Armstrong, 2017). Culture is a factor that determines the desires and behavior of individuals that are fundamental in purchasing behavior and purchasing decision making (Setiadi, 2003). Social factors include small groups of consumers, social networks, families, and social roles and status. Personal characteristics include work, age, economic conditions, lifestyle, personality and self-concept. Psychological factors include motivation, perception, learning, and beliefs and attitudes. A person has many needs at a certain time. Some are biological, arising from tense conditions such as hunger, thirst, or discomfort (Kotler \& Armstrong, 2017).

Based on the facts that have been stated earlier, then the specific question that arises is whether the quality of photos uploaded by tourists (UGC) on Instagram influences the decision of visiting potential tourists? The question arises because many new attractions are popularized through photo uploads by Instagram users, especially tourists belonging to the millennial generation. Cheong \& Morrison (2008) suggest that UGC is more trusted because it has no commercial interests and is an impartial appraiser of the quality of a product or service. UGCs obtained from friends and family are considered more authentic in providing a description of the condition of a destination compared to content that comes from official institutions (Deng et al., 2019; Lo et al., 2011). Consumers consider that UGC sources, for example bloggers, uploaders of videos and photos are more credible than the content produced by the company (Jonas, 2010). They also consider UGC as a useful aid in making purchasing decisions (Cheong and Morrison, 2008). Tourists are willing to spend a lot of money on a product that they cannot see, so they are very interested in being involved in the decision making process (Horner \& Swarbrooke, 2007). In recent years, usergenerated media has become an important tool used by tourists to try and reduce the risk of buying this intangible product (Horner \& Swarbrooke, 2016).

One of the potential tourist attractions is located in West Bandung Regency (KBB). West Bandung has a variety of natural and cultural charms. All of this natural wealth and cultural diversity are potential tourist attractions which, if managed and promoted effectively, will be the main capital for the growth of the 
tourism sector in West Bandung and can provide economic benefits for the surrounding community. One form of promotion or marketing can be done by utilizing photo uploads uploaded by tourists (UGC) who have visited tourist attractions at West Bandung.

Based on the background stated above, this study intends to reveal how much influence the quality of photo uploads on Instagram on the decision of millennial tourists visiting on tourist attractions in West Bandung Regency. The details are as follows: 1 . To get an idea of the quality of photos uploaded by tourists (UGC) on Instagram, 2. To get an idea of the decision to visit millennial tourists on tourist attractions in West Bandung Regency, 3. To reveal how much influence the quality of photos uploaded by tourists (UGC) on the decision to visit millennial tourists on tourist attractions in West Bandung Regency

\section{Methods}

The research method used in this study is a descriptive verification method that aims to test the causal truth, which is to find out how much influence the quality of photos uploaded by tourists (UGC) on the decision of visiting millennial tourists on tourist attractions in West Bandung Regency. This study also aims to obtain the truth of a hypothesis that is carried out through data collection in the field.

Data collection instruments about photo upload quality refer to dimensions developed by Peterson (2010) which consist of: aperture (diaphragm), shutter speed (ISO shutter speed) and ISO (storage media sensitivity) and tourist visiting decisions refer to dimensions developed by Kotler \& Keller (2016) consisting of: cultural, personal, social and psychological factors.

The population in this study were millennial tourists visiting destinations in the West Bandung area in April 2019. Through the convenience sampling technique, 169 samples were collected. To find out the magnitude of the influence of the independent variable (the quality of photo uploads) on the dependent variable (the decision to visit) both together or partially using multiple linear analysis techniques.

\section{Finding and Discussion}

\subsection{Picture quality of photos uploaded by tourists (UGC) on Instagram.}

The following is a recapitulation of tourist responses about the quality of photos uploaded by tourists (UGC) on Instagram.

Table 1 Recapitulation of Traveler Responses about Photo Quality Uploaded by tourists (UGC) on Instagram

\begin{tabular}{|c|c|c|c|}
\hline Dimension & Total Score & Average Score & Percentage \\
\hline Diafragma & 622 & 311 & 31,1 \\
\hline Shutter & 728 & 364 & 46,4 \\
\hline Iso & 325 & 325 & 32,5 \\
\hline TOTAL & 1675 & 1000 & 1000 \\
\hline
\end{tabular}

Based on Table 1 above, it can be seen that the sub-variable that achieves the highest rating of the photo upload quality variable is the shutter/shutter with an average score of 364 and a percentage of $36.4 \%$. Variable X (photo upload quality) gets a score of 1675 and when presented in an ideal score, which is 2000, a percentage value of $83.75 \%$ is obtained. Thus the continuum is described as follows. 


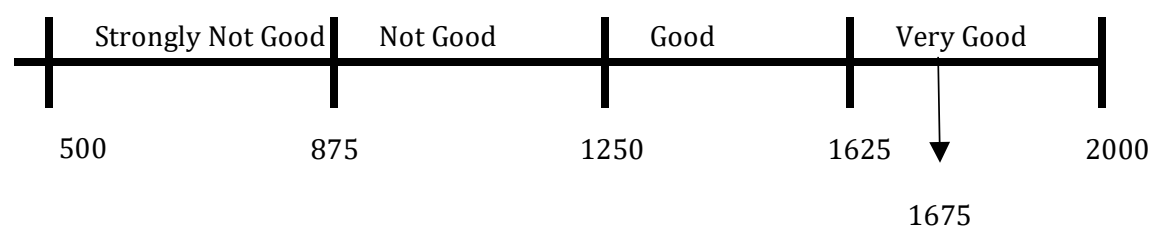

Fig. 1 Continuum Line Quality Photos Uploaded By Travelers (UGC) on Instagram

Based on the recapitulation and continuum lines of the Photo Quality variable above, it can be concluded that the overall response of respondents about the quality of photos uploaded by travelers (UGC) on Instagram which includes diaphragm, shutter, and ISO are in the very good category.

Photo media is one of the communication media that can be used to convey messages or ideas to others. Media photo or photography is a media that can be used to document an important moment or event. In its use, photos have a deeper meaning than verbal language (Barnbaum, 2010). With the rapid development of UGC data, more and more tourists are sharing their tourist experiences by posting relevant information and photos online. Photos are a major component of UGC, because photos provide abundant information about travel and tourism (Deng et al., 2019).

The findings of this study indicate that tourists give excellent appreciation and ratings to photographs uploaded by tourists who have visited KBB. If seen from the scores obtained, the highest score acquisition is the assessment of the shutter sub variable. Thus tourists assess the photos uploaded by tourists who have visited KBB on Instagram have a good level of sharpness and clarity. While the acquisition of the lowest score is the assessment of the diaphragm sub variable. A diaphragm or aperture is a measure of the size of the lens opening. Use to regulate the level of light entering the film or to regulate the quantity of light. This finding can be exploited by tourism actors, especially by tourism marketers. Through a tourist permit that uploads photos, marketers can use these photos to market certain tourist attractions, taking into account the weaknesses and strengths that have been found in this study.

\subsection{Description of the decision to visit millennial tourists on the tourist attraction in West Bandung Regency.}

The following is a recapitulation of tourist responses regarding the decision to visit millennial tourists on the tourist attraction in West Bandung Regency.

Table 2 Recapitulation of Tourist Responses on Millennial Tourist Decisions on Tourism Attractions in West Bandung Regency

\begin{tabular}{lccc}
\hline \multicolumn{1}{r}{ Dimension } & Total Score & Average Score & Percentage \\
\hline Culture & 682 & 341 & 26,31 \\
Social & 636 & 318 & 24,54 \\
Personal & 911 & 303 & 23,38 \\
Psychology & 1674 & 334 & 25,77 \\
\multicolumn{1}{c}{ TOTAL } & $\mathbf{3 9 0 3}$ & $\mathbf{1 0 0 0}$ & $\mathbf{1 0 0 0}$ \\
\hline
\end{tabular}

Based on Table 2 above, it can be seen that the sub-variable that achieves the highest rating of the tourist visiting decision variable is the cultural sub-variable with an average score of 341 and a percentage of $26.31 \%$. Variable X (tourist visiting decision) gets a score of 3903 and when it is presented into an ideal score, which is 4800 , a percentage value of $81.31 \%$ is obtained. Thus the continuum is described as follows. 


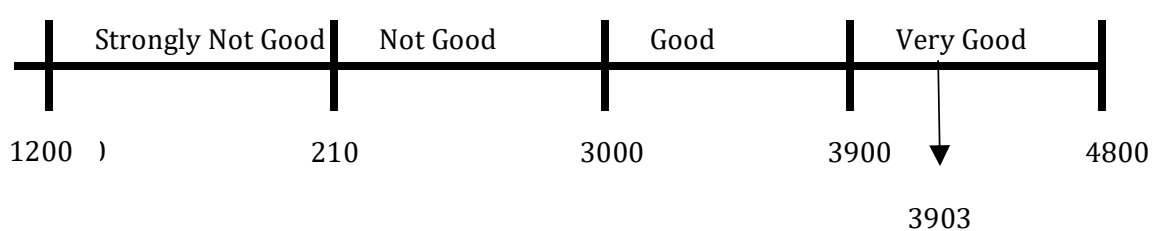

Fig. 2 Continuum Lines for Millennial Tourist Decisions on Tourism Attractions in West Bandung Regency

Based on the recapitulation and continuum lines of the tourist visiting decision variables above, it can be concluded that the overall response of respondents regarding the decision to visit millennial tourists on tourist attractions in West Bandung Regency which includes cultural, personal, social, and psychological factors which are in the good category.

According to Kotler \& Keller (2016), purchasing decision making is the study of how individuals, groups, and organizations choose, buy, use goods, services, ideas, or experiences to satisfy their needs and desires. In the context of tourism, choosing a destination and planning a trip is a complex decision-making process because of the intangible nature of its services. The findings of this study indicate that the decision to visit tourists at KBB is in the very good category. If seen from the scores obtained, the highest score acquisition is the assessment of cultural sub-variables. Culture is the most fundamental cause of one's desires and behavior. Human behavior is largely studied. Setiadi (2003) says that culture is a factor that determines the desires and behavior of individuals that are fundamental in purchasing behavior and purchasing decision making. In fact, tourists visiting destinations at KBB are based on their wants and needs. In addition, the activities that can be carried out at KBB are not much different from the daily activities that they usually do.

\subsection{The effect of the quality of photos uploaded by tourists (UGC) on the decision to visit millennial tourists on tourist attractions in West Bandung Regency.}

The hypothesis to be tested is:

H0: there is no significant effect on the uploaded photo quality variable on tourist visiting decisions. Ha: there is a significant influence on the uploaded photo quality variable on tourist visiting decisions.

Based on the F test the F count is 19.59 and the $\mathrm{F}$ table is 2.06. Because the value of $\mathrm{F}$ arithmetic $>\mathrm{F}$ table, then $\mathrm{HO}$ is rejected, meaning that there is a significant influence on the uploaded photo quality variable on tourist visiting decisions. The findings of this study are in line with research conducted by Kim \& Stepchenkova (2015) who found the influence of photos on the desire to visit, Pan et al., (2014) research concluded that there was a correlation between photo content and tourist motivation, research conducted by Windani (2016) which states that there is an effect of uploading photos on Instagram on visiting behavior, Tambunan's research (2016) found a social media influence on visiting decisions, and Munawaroh's research (2018) which revealed the influence of photos uploaded on Instagram accounts on visiting interests. Some of the research findings indicate that photographs have a very important role in tourism, as revealed by Garrod (2008) MacKay \& Fesenmaier (1997), Markwell (1997), that photography is an integral part of the traveling experience, and sharing photos is an important activity in documenting, animating and sharing these experiences. Photos provide abundant information about travel and tourism (Deng et al., 2019)

Photos uploaded by tourists (UGC) will greatly affect the decision of visiting other potential tourists, especially millennial tourists because they are considered more authentic in providing a description of the condition of a destination compared to content originating from official institutions (Deng et al., 2019; Lo et al., 2011), more credible than the content produced by the company (Jonas, 2010). The findings of this study found that photos uploaded by tourists in KBB affect the decision of visiting potential tourists because in this study it was found that most of the activities carried out by tourists visiting KBB were taking selfies (37 tourists). The factor that caused it was because KBB had Instagram-able photo spots that were very suitable to be captured and uploaded on Instagram.

\section{Conclusion}

The quality of photos uploaded by tourists (UGC) on Instagram which includes diaphragm, shutter/shutter, and ISO is in the very good category. The sub variable that achieves the highest rating of the photo upload 
quality variable is the shutter/shutter sub. This means that tourists who assess UGC on Instagram have a good level of sharpness and clarity.

The decision to visit millennial tourists on tourist attractions in West Bandung Regency which includes cultural, personal, social, and psychological factors is in the very good category. The sub-variables that achieves the highest assessment of the visiting decision variable is cultural sub-variable. There is a significant influence on the uploaded photo quality variable on tourist visiting decisions. The percentage or effect of the independent variables on the dependent variable is $33.64 \%$, while the remaining $66.36 \%$ is explained by other variables not included in this research model.

\section{References}

Bagadiya, J. (2017). 151 amazing social media statistics you should know in 2017. Retrieved from Socialpilot website: https://socialpilot.co/blog/151-amazing-social-media-statistics-know-2017/

Barnbaum, B. (2010). The Art of Photography: An Approach to Personal Expression. Santa Barbara: Rocky Nook.

Burhanuddin. (2014). Fotografi. Yogyakarta: Graha Ilmu.

Carr, C. T., \& Hayes, R. A. (2015). Social Media: Defining, Developing, and Divining. Atlantic Journal of Communication, 23(1), 46-65. https://doi.org/10.1080/15456870.2015.972282

Cheong, H. J., \& Morrison, M. A. (2008). Consumers reliance on product information and recomendations found in UGC. Journal of Interactive Advertising, 38-49.

Debby, L. T. (2016). Pengaruh Social Media Terhadap Keputusan Berkunjung Wisatawan Nusantara ke DKI Jakarta. Sekolah Tinggi Pariwisata Bandung, Bandung.

Deng, N., Liu, J., Dai, Y., \& Li, H. (2019). Different cultures, different photos: A comparison of Shanghai's pictorial destination image between East and West. Tourism Management Perspectives, 30, 182-192. https://doi.org/10.1016/j.tmp.2019.02.016

Garrod, B. (2008). Understanding the Relationship between Tourism Imagery and Tourist Photography. Journal of Travel Research, 47(3), 346-358. https://doi.org/https://doi.org/10.1177

Hasan, A., \& Setiyaningtiyas, N. W. (2015). Pengaruh Electronic Word Of Mouth Pada Media Sosial Face-book Terhadap Keputusan Berkunjung Ke Desa Wisata Nglanggeran Gunung Kidul. Jurnal Media Wisata, 13(1), 224-238. https://doi.org/https://doi.org/10.36276/mws.v13i1.80

Horner, S., \& Swarbrooke, J. (2007). Consumer Behaviour in Tourism. Elsevier.

Horner, S., \& Swarbrooke, J. (2016). Consumer Behaviour in Tourism. Routledge.

Jonas, J. R. (2010). Source credibility of company-produced and user generated content on internet: An exploratory study on the filipino youth. Philipine Management Review, 121-132.

Kaifi, B. A., Nafei, W. A., Khanfar, N. M., \& Kaifi, M. M. (2012). A Multi-Generational Workforce: Managing and Understanding Millennials. International Journal of Business and Management, 7(24), 88-93. https://doi.org/10.5539/ijbm.v7n24p88

Kaplan, A. M., \& Haenlein, M. (2010). Users of the world, unite! The challenges and opportunities of Social Media. Business Horizons, 53(1), 59-68. https://doi.org/10.1016/j.bushor.2009.09.003

Kim, H., \& Stepchenkova, S. (2015). Effect of tourist photographs on attitudes towards destination: Manifest and latent content. Tourism Management, 49, 29-41. https://doi.org/10.1016/j.tourman.2015.02.004

Kotler, P., \& Armstrong, G. (2017). Principles of Marketing 17th Global Edition (17th ed.). Pearson. 
Kotler, P., \& Keller, K. L. (2016). Marketing Management 15th Edition. Pearson.

Lo, I. S., McKercher, B., Lo, A., Cheung, C., \& Law, R. (2011). Tourism and online photography. Tourism Management, 32(4), 725-731. https://doi.org/10.1016/j.tourman.2010.06.001

MacKay, K. J., \& Fesenmaier, D. R. (1997). Pictorial element of destination in image formation. Annals of Tourism Research, 24(3), 537-565. https://doi.org/10.1016/S0160-7383(97)00011-X

Markwell, K. W. (1997). Dimensions of photography in a nature-based tour. Annals of Tourism Research, 24(1), 131-155. https://doi.org/10.1016/S0160-7383(96)00053-9

Munar, A. M., \& Jacobsen, J. K. S. (2014). Motivations for sharing tourism experiences through social media. Tourism Management, 43, 46-54. https://doi.org/10.1016/j.tourman.2014.01.012

Munawaroh, P. R. (2018). Pengaruh Terpaan Media Pada Akun Instagram @Exploresiak Terhadap Minat Kunjungan Wisata Ke Siak Sri Indrapura. JOM FISIP, 5(1), 1-13. Retrieved from https://media.neliti.com/media/publications/199786-none.pdf

Mustikasari, A., \& Widaningsih, S. (2017). PENGARUH E-WOM TERHADAP KEPUTUSAN BERKUNJUNG KE TEMPAT WISATA DI KOTA BANDUNG. Jurnal Manajemen Indonesia, 16(2), 95. https://doi.org/10.25124/jmi.v16i2.315

Pan, S., Lee, J., \& Tsai, H. (2014). Travel photos: Motivations, image dimensions, and affective qualities of places. Tourism Management, 40, 59-69. https://doi.org/10.1016/j.tourman.2013.05.007

Parker. (2016). A long list of Instagram statistics that marketers need to know. Retrieved from https://blog.hootsuite.com/instagram-statistics/

Pemerintah Indonesia. Undang-Undang No. 40 Tahun 2009 tentang Kepemudaan. Lembaran Negara RI Tahun 2009, No. 148., 2009 § (2009).

Peterson, B. (2010). Understanding Exposure. AmPhoto Books.

Prensky, M. (2010). Partnering for Real Learning. In M. Prensky (Ed.), Teaching Digital Natives (pp. 9-29). California.

Setiadi. (2003). Perilaku Konsumen : Konsep dan Implikasi. Jakarta: Kencana.

Smith. (2016). 96 Amazing Social Media and Facts. Retrieved from https://www.brandwatch.com/blog/96amazing-social-media-statistics-and-facts-for2016/

Tambunan, D. L. (2016). Pengaruh Social Media Terhadap Keputusan Berkunjung Wisatawan Nusantara Ke DKI Jakarta. Sekolah Tinggi Pariwisata Bandung, Bandung.

Windani, A. (2016). Pengaruh Unggahan Foto Wisata Alam Yogyakarta Pada Media Sosial Instagram Terhadap Perilaku Berkunjung. Universitas Islam Negeri Yogyakarta.

Woodside, A. G., \& Lysonski, S. (1989). A General Model Of Traveler Destination Choice. Journal of Travel Research, 27(4), 8-14. https://doi.org/10.1177/004728758902700402

Xiang, Z., Magnini, V. P., \& Fesenmaier, D. R. (2015). Information technology and consumer behavior in travel and tourism: Insights from travel planning using the internet. Journal of Retailing and Consumer Services, 22, 244-249. https://doi.org/10.1016/j.jretconser.2014.08.005 